\title{
The origins and future of patriarchy: the biological background of gender politics
}

\author{
Malcolm Potts, Martha Campbell
}

\section{Introduction}

Langur monkeys live in social groups consisting of several females and their offspring together with one alpha male, who fights off other males and controls the females. When primatologist Sarah Hrdy studied these monkeys in the 1970 s, she found that after an alpha male was defeated then the new dominant male set about systematically to kill the suckling infants sired by the previous male. Like everything in evolution this is not a conscious strategy, but those males who had a mutation coding such behaviour would have left more genes in the next generation, because killing the baby cut short the interval of lactational amenorrhoea making the female immediately available for impregnation by the new male.

Female langur monkeys try to defend their infants from the murderous males but eventually the stronger male wins. Commenting on the differing reproductive agenda Hrdy has written: "In only a few cases will the self interest of consorts overlap".1 A parallel behaviour has also evolved in lions and gorillas - and it seems in Homo sapiens. Daly and Wilson, using criminological data from North America, have shown that the relative risk of a non-biological father killing the child of the women he has sex with is 60 times greater than that of a biological father. ${ }^{2}$ This effect lasts for precisely the time we would expect a woman to breastfeed in a hunter-gather society. As every epidemiologist knows, a 60 -fold risk is a compelling statistic.

Darwin was the first person to understand that men and women can have different reproductive agendas for explicable biological reasons. He saw that what he called the "war of nature" exists not only between species, but also between the two sexes of the same species. Commenting on sexual dimorphism, where the male is bigger than the female, Darwin wrote: "the male ... seems to owe his greater size to his ancestors having fought with other males during many generations". 3

Sexually dimorphic species are either polygamous or promiscuous in their mating patterns, while among genuinely monogamous species (e.g. penguins) the two sexes are the same size, or the male is smaller. The fact that men, on average, are 5-12\% larger than women ${ }^{4}$ and have greater upper body strength betrays the fact that we are descended from a promiscuous or polygynous hominid stock. Although behaviour itself does not fossilise, a lot can be inferred from dry bones and studies of australopithecine fossils, which suggest the males matured more slowly and grew to be larger than females. 5

Those working in reproductive health are vividly aware of how much more time and energy a woman puts into pregnancy and lactation than a man puts into depositing sperm. Evolution predicts that the sex making most

J Fam Plann Reprod Health Care 2008; 34(3): 171-174

University of California at Berkeley, School of Public Health, Berkeley, CA, USA

Malcolm Potts, MB BChir, PhD, Bixby Professor

Martha Campbell, PhD, Lecturer

Correspondence to: Professor Malcolm Potts, University of California at Berkeley, School of Public Health, 207G University Hall, Berkeley, CA 94720-7360, USA.

E-mail: pottsmalcolm@yahoo.com biological investment in the next generation will be cautious in their mating choices, while the one that makes the least investment is likely to be more competitive, less discriminating and more risk-taking. It is a generalisation borne out by the behaviour of all other species, including our own. Evolutionary psychology posits that certain behaviours are universal because they helped the genes of a particular species to survive across the generations. In the case of human beings, such behavioural predispositions evolved to adapt us to the Stone Age rather the modern world. Patriarchy, we suggest, has deep roots in human evolution. 6

\section{The rise of patriarchy Hunter-gatherer societies}

For over $95 \%$ of the time since Homo sapiens became a distinct species, we lived in small hunter-gatherer clans, and some survive today. Among such societies, the menarche often occurs in the late teens, and pregnancies are naturally spaced by long intervals of breastfeeding. The total fertility rate is between 3.5 and $7.8 .^{7}$ As among other sexually dimorphic primates, some men in hunter-gatherer societies use their greater strength to dominate women. Among the Yanomamo of Venezuela and Brazil, some men beat their wives with sticks, cut them with machetes, hold hot timbers against them, or even fire a barbed arrow into the buttocks. 8 Among the less violent !Kung of the Kalahari some men still try to dominate women. A woman's brothers may sometimes come to the rescue of a woman ill treated by her husband. In a society without property, a woman may walk away from violence although she will have to continue to support any children. ${ }^{9}$

Some preliterate societies are slightly less paternalistic than others. While the myth of some sort of ancestral matriarchal society has attracted some writers, it has no foundation in anthropology or history. For example, in some hunter-gatherer societies the girl's family decides whom she will marry, or in more war-like tribes women are captured, raped and then assigned to a particular man. Sometimes men and women choose their sexual partners, as among the Ayoreo in Paraguay, where young men and women make romantic attachments. Anthropologists Bugos and McCarthy describe Ayoreo women as a "charming friend, devoted wife and doting mother". However, up to one-third of firstborn children are killed at birth by their mothers. ${ }^{10}$ In this case women are optimising their reproductive potential over the long term, because if a romantic relationship fails, a woman will not receive the support she needs from the father of the child, while over the next few years of breastfeeding and childcare she will be excluded from exploring a new romantic relationship. The most cost-effective reproductive strategy is to kill the child and start again. The older the woman, the less effective this strategy, and female infanticide falls with the mother's age. In the West, women make similar decisions over optimising their lifelong reproductive potential, but they do so through contraception and abortion.

\section{Despotic societies}

Across history and across cultures, rich and powerful men have had more sex than those lower in the social hierarchy. Large harems were the order of the day for King Solomon, the Pharaohs of Egypt, the Aztec Kings, the Mongol rulers, 
the Turkish Sultans and the Chinese Emperors. The 19th century kings of Dahomey had harems of literally thousands of women. Some of the many women belonging to the king were drafted as a bodyguard, the so-called 'Amazons'. ${ }^{11}$ Some $8 \%$ of men in Central Asia and one in 200 men world wide have an identical Y chromosome and the most plausible explanation of this curious fact is that these men are all descendents of Genghis Khan (d. 1227). $\mathrm{He}$ had a large harem and delighted in raping women captured in warfare, and his children behaved the same way through out the following century. ${ }^{12}$ In Ireland, a study of the Y chromosome of almost 800 men found many shared a common genetic signature thought to show descent from a Dark Age despot called Niall. Ui Neill is an Irish surname meaning "descendent of Niall", and studies show that men with this name are likely to have an identical $\mathrm{Y}$ chromosome. ${ }^{13}$ Keeping a harem not only enables a despot to father many children, but it also deprives other men of wives. In pre-conquest Peru, the great Inca at the top of the social pyramid had the pick of the empire and the men at the bottom often went unmarried. In Dahomey, the king was forced to subsidise prostitution for those who could not find a wife, bringing the price of sex down to one-tenth the cost of a dead chicken.11

Despots imposed patriarchal laws with ferocious consistency. Rich men cloistered their women behind high walls, or bound their feet so they could neither work in the field nor run away. If a man had intercourse with one of the 700 wives of the Great Inca, then the guilty man was executed along with his wife, relatives, servants, all the people in his village and his farm animals, "without leaving a suckling nor a crying baby". 14

The occasional Roman emperor, such as Trajan, was less despotic than others and did not keep a large harem, but Emperor Commodus is said to have had 300 concubines $^{13}$ and every male slave owner had automatic sexual rights over any slave he found attractive. It was in this world that the Christian teaching about sex arose. St Augustine (d. $430 \mathrm{AD}$ ) saw God as an arbitrary judge who could be placated by bribes. We still speak of patron saints because it was the patroni who paid bribes, or gracia (hence the theological word grace) to Roman judges. ${ }^{15}$ Augustine taught that Original Sin had been transmitted, like some latter-day AIDS virus, through sexual intercourse since Adam disobeyed God in the Garden of Eden. It followed, argued Augustine, that unbaptised children would burn in Hell for all eternity and that the only justification for sexual intercourse was to father children. He wrote: "That which cannot be done without lust must be done in such a way that it is not done for lust". Contraception was anathema and over a millennium later, in 1532, Article 133 of the Penal Code of the Holy German Emperor prescribed death (beheading for men and drowning for women) for the use of contraception or abortion of an animated fetus. Patriarchy was not just men controlling women, but men degrading and hating women because Eve had enticed Adam.

As with Christianity, Islam has liberal and conservative interpretations of female sexuality. The position of women in Afghanistan is as bad as it was in medieval Europe and under the Taliban (whose power is returning in parts of the county) it was even worse. Women were compelled to wear the all-enveloping burqa in public and house windows had to be painted black in case someone outside caught a glimpse of a woman in her home. Women were barred from attending the general hospital in Kabul, because they were not allowed to mix with male patients. Co-educational schools were closed, preventing the majority of girls from receiving even a primary education.

\section{Fading patriarchy}

The long history of the nuclear family in parts of Western Europe, sometimes associated with relatively late marriage, slowly gave some women more autonomy than they enjoyed in many other societies. In 14th century England, Chaucer's Wife of Bath extols sexual pleasure and flaunts her independence. Some couples found genuine love, as did Anne Dudley Bradstreet who in 1628 married a man of 24 when she was 15 or 16 . She bore him eight children. An accomplished poet, she wrote: "If ever two were one, then surely we/If ever man were lov'd by wife, then thee/If ever wife was happy in a man/Compare with me ye women if you can". 16

By the 18th century in parts of Europe and North America romantic love began to be celebrated in literature; but for the poor wife of a subsistence farmer or a factory worker, patriarchy reigned with few limitations. One of the sensible things Karl Marx's colleague Friedrich Engels wrote was: "the first class oppression coincided with that of the female sex by the male". 17 In particular, laws related to property and to divorce reinforced patriarchy.

Predictably, the early 19th century Freethinkers (today they would be called agnostics or humanists) became the first to attempt to pry open the iron jaws of patriarchy. Francis Place (who had 15 children) began to promote sponges as vaginal barriers and John Stuart Mill was arrested for handing out leaflets on contraception. ${ }^{18}$ But most women had no access to even the simplest contraceptive and abortion was illegal throughout North America, Europe and the colonies of the industrialised nations. Lacking effective contraception and thrown into the new world of urban living, 18th and 19th century women, like the Ayoreo, in order to optimise lifelong reproduction, resorted to killing their infants, only they did it indirectly by placing their unintended children in foundling hospitals. Without breastfeeding, or even clean water, 10204 of the 14934 babies admitted to the London Foundling Hospital in the 1770 s died. 15

\section{The shadow of patriarchy}

By 1919 the birth rate in Belgium had fallen slightly compared with 1880-1910 in those arrondissements that voted for Catholic political parties but by up to $80 \%$ in those which had turned their back on religious patriarchy. 19 Throughout the rest of the 20th century and into the 21st, patriarchy has continued to cast a sinister shadow. In North America, the National Institutes of Health (NIH) was forbidden to sponsor contraceptive research until 1968. Even today, the NIH is not permitted to fund research on possible abortifacient drugs. In Ireland, the Family Planning Association was fined $£ 500$ in 1990 for selling a condom in the Virgin Music Megastore in Dublin.

The asymmetry in the history of oral contraceptives (OCs) and therapies for erectile dysfunction (ED) is particularly revealing. ${ }^{20}$ The physiological basis of hormonal contraception was described in 1921, but it took three decades before Margaret Sanger could persuade scientists to develop the first OC. And when they did, contraception was still illegal in Massachusetts and no large pharmaceutical company wanted to touch the new product. There were no laws against studying male erections, and when Viagra ${ }^{\circledR}$ was discovered it was developed immediately as a blockbuster drug.

In 1962, the Second Vatican Council replaced a theology of marriage based exclusively on the procreation of children by one built on mutual love, and the teaching on contraception was expected to change, at least in relation to the newly invented OCs. The Harvard obstetrician, John Rock, who led the clinical work on the first OCs, was a 
devout Roman Catholic who attended Mass every morning. In 1963 he wrote The Time Has Come, arguing the Pill was morally appropriate because it merely extended the natural suppression of ovulation during lactation. The Vatican responded by establishing a Commission to study contraception. The majority agreed that the Pill was theologically acceptable, but in July 1968 Pope Paul IV issued the encyclical Humanae Vitae, to: "exclude ... any action ... specifically intended to prevent procreation whether as an end or a means". John Rock and millions of others stopped going to Mass. The Pope was reaffirming Saint Augustine's denial of the dual biological purposes of human intercourse. ${ }^{21}$

Referring to nocturnal erections, Augustine wrote: "these members are rightly called pudenda [parts of shame] because they excite themselves just as they like, in opposition to the mind of their master as if they were their own masters". Yet no theologian or prelate has condemned Viagra or Levitra ${ }^{\circledR}$ for encouraging the "parts of shame to excite themselves". Every death with the original highdose OCs hit the headlines, and the United States Congress considered taking the Pill off the market. Over 500 deaths ${ }^{22}$ have been reported with ED therapies, including perhaps one head of state - President Abacha of Nigeria. As in the case of OCs, ED deaths are not necessarily causally related, but nevertheless it is perhaps revealing that there has been no call to take these drugs off the market. In fact, many North American medical insurance companies have been quicker to pay for ED therapies than OCs.

Evolutionary psychology looks for behaviours which are universal and the shadow of yesterday's patriarchal traditions are not limited to the West. Efforts to register OCs in Japan began in 1965. Initially, use was refused because Japanese women were said to be physiologically different from Western women; then it was said OC use would spread HIV; finally in 1998 registration was refused for a reason paralleling the obscurantism of medieval theologians - it was claimed that artificial hormones in sewage would feminise fish. The following year, Viagra was approved in a record short time of 6 months. Eventually, the asymmetry between the two drugs had become so grotesque that the Pill was finally approved on Viagra's coat tails, 35 years after the initial application.

\section{The end of patriarchy?}

The fight for reproductive rights and freedom can be seen as a long, painful struggle between the evolved male reproductive agenda, which is predisposed to control female patterns of mating and childbearing, and the female reproductive agenda, which benefits from the widest possible choice of mate and freedom to optimise lifelong patterns of childbearing. No woman can be free unless she can control if and when to have children. Male attempts to control female reproductive choices have a long history. It was women who discovered and marketed most traditional contraceptives and abortifacients, and men who wrote laws and preached theological arguments to restrict or condemn their use.

Evolution is the outcome of random mutations, tested in the real world of natural competition. Evolution is about what works; not what is fair, moral or just. The insights that can be drawn from evolutionary psychology are not excuses for cruelty, but insights that can help us confront cruelty and injustice. This is particularly important when we are trying both to understand the origins of human patriarchy and striving to eliminate patriarchy in the future.

Patriarchy has deep roots in human behaviour, a terrible record of pain and suffering in historic societies, and even today patriarchal forces in many developing countries continue to enslave half the human race and remain near the surface in the West. When young American men were asked to imagine what they would do if they could rape a woman and be certain they would never be found out, onethird said they might rape..$^{23}$

While 185 countries have ratified the 1979 Convention on the Elimination of All Forms of Discrimination Against Women, hundreds of millions of women still suffer from violence, sexual abuse and unequal access to the law. Gonoshasthaya Kendra ("People's Health Centre") is a non-governmental organisation in Bangladesh that has brought about substantial improvements in maternal and infant mortality and worked hard to improve the status of women. Yet when a careful review was conducted of 616 consecutive deaths in women aged 15 to 49 years, $14 \%$ of women's deaths were related to pregnancy and childbirth, and a remarkable $5.5 \%$ committed suicide as a result of domestic violence and abuse by in-laws. ${ }^{24}$ Even today, a pregnant woman in the USA is more likely to be murdered, nearly always by a sexual partner, than to die of any single disease during pregnancy, such as heart or kidney failure. To return to Saint Augustine, he explicitly praised his own mother, Monica, for never complaining about his father's infidelities, maintaining that the correct way to escape domestic violence was for a wife never to criticise her husband, however badly he treated her.

From the Stone Age to the second Bush administration, the male predisposition to dominate the reproductive lives of women often holds sway. Britain is discussing whether pharmacists should distribute OCs more than three decades after the evidence base for non-physician prescription was established. In the USA, the Bush administration has overridden expert advice on emergency contraception and censored statements on condoms. It is useful, we suggest, to see such arguments as less about morals and more about patriarchy. Looked at this way, then Britain and the other developed nations should be as eager to bring contraception and safe abortion to women in the developing world in the 21 st century as they were to end slavery in the 19th century.

Statements on funding and competing interests

Funding None identified.

Competing interests None identified.

References

1 Hrdy SB. The Langurs of Abu: Female and Male Strategies of Reproduction. Cambridge, MA: Harvard University Press, 1977.

2 Daly M, Wilson M. Homicide. New York, NY: Aldme de Gruyter, 1988.

3 Darwin C. The Descent of Man and Selection in Relation to Sex. First edition published in 1871 .

4 Alexander RD, Hoogland JL, Howard RD, Noonan KM, Sherman PW. Sexual dimorphism and breeding systems in pinnipeds, ungulates, primates and humans. In: Chagnon NA, Irons W (eds), Evolutionary Biology and Human Social Behavior: An Anthropological Perspective. North Scituate, MA Duxbury Press, 1979; 401-435.

5 Lockwood CA, Menter CG, Moggi-Cecchi J, Keyser AW. Extended male growth in a fossil hominin species. Science 2007; 318: 1443-1446.

6 Smuts B. The evolutionary origins of human patriarchy. Hum Nature 1995; 6: 1-32.

7 Campbell KL, Wood JW. Fertility in traditional societies. In: Diggory P, Potts M, Tepper S (eds), Natural Human Fertility: Social and Biological Determinants. London, UK: Macmillan, 1988; 39-69.

8 Chagnon NA. Yanomamo (5th edn). Fort Worth, TX: Harcourt Brace College Publishers, 1997

9 Shostak M. Nisa: The Life and Words of a !Kung Woman. Cambridge, MA: Harvard University Press, 1981.

10 Bugos PE, McCarthy LM. Ayoreo infanticide: a case study. In: Hausfater G, Hrdy SB (eds), Infanticide: Comparative and Evolutionary Perspectives. New York, NY: Aldine Publishing Company, 1984; 503-520. 
11 Edgerton RE. Warrior Women: The Amazons of Dahomey and the Nature of War. Boulder, CO: Westwood Press, 2000; 45.

12 Zerjal T, Xue Y, Bertorelle G. The genetic legacy of the Mongols. Ann Hum Genet 2003; 72: 717-721.

13 Moore LT, McEvoy B, Cape E, Simms K, Bradley DG. A Ychromosome signature of hegemony in Gaelic Ireland. Am J Hum Genet 2006; 78: 334-338.

14 Betzig LL. Despotism and Differential Reproduction: A Darwinian View of History. New York, NY: Aldine Publishing Company, 1986.

15 Potts M, Short R. Ever Since Adam and Eve: The Evolution of Human Sexuality. Cambridge, UK: Cambridge University Press, 1999.

16 Yalom M. A History of the Wife. New York, NY: HarperCollins, $2001 ; 130$

17 Engels F. The Origin of the Family, Private Property and the State. New York, NY: International Publishers, 1964; 58.

18 Potts M, Campbell M. History of contraception. In: Sciarra J (ed.), Gynecology and Obstetrics (CD-ROM 2003 edition). Philadelphia, PA: Lippincott Williams and Wilkins, 2003; Vol. 6, Chapter 8
19 Lesthaeghe RJ. The Decline of Belgium Fertility. Princeton, NJ: Princeton University Press, 1977; 229.

20 Potts M. Two pills, two paths: a tale of gender bias. Endeavour 2003; 27: 127-130.

21 Potts M. The evolution of human sexual intercourse. A revisited philosophy: sex without reproduction. In: Benangiano G, Di Renzo GC, Cosmi EV (eds), The Evolution of the Meaning of Sexual Intercourse in the Human. Cortona, Italy: da Editirice Grafica l'Etruria, 1996

22 Du X. "Viagra deaths explained by new understanding of platelet clumping." Science Blog, University of Illinois at Chicago, January 2003. http://www.scienceblog.com/ community/older/2003/B/20036497.html [Accessed 14 January 2008].

23 Thornhill NW, Thornhill R. An evolutionary analysis of psychological pain following rape. Ethol Sociobiol 1990; 11: 155-193.

24 Chowdhury RH, Chowdhury Z. Achieving the Millennium Development Goal on Maternal Mortality; Gonoshathaya Kendra's Experience in Rural Bangladesh. Dhaka, Bangladesh: Gonoprokashani, 2007.

\section{JOURNAL REVIEWS}

Effects of continuous versus cyclical oral contraception: a randomized controlled trial. Legro RS, Pauli JG, Kunselman AR, Meadows JW, Kesner JS, Zaino RJ, et al. J Clin Endocrinol Metab 2008; 93: 420-429

There is continuing interest in the use of longcycle and continuous combined hormonal contraceptive regimens to improve premenstrual and menstrual ill-health. This paper is a welldesigned, randomised, double-blind trial involving a total of 62 healthy women taking either combined pills for 21 days plus 7 days of placebo over six cycles or continuous therapy for 168 days.

It was surprising to see that a $20 \mu \mathrm{g}$ ethinylestradiol and $1 \mathrm{mg}$ norethindrone acetate pill was chosen for this study. The authors explained that previously published work had reported more days of amenorrhoea and fewer days of spotting with such a preparation.

The subjects were studied for three menstrual cycles prior to enrolment. No hormonal contraception was taken during this time. They were then seen regularly during the 'active' phase of the study.

Just under $20 \%$ of women dropped out once taking the study medication with approximately half giving 'uncomfortable with the side effects' as their reason. The overall results are similar to previous published work with the total number of bleeding days similar between the two groups but significantly less moderate/heavy bleeding days occurring with the continuous therapy(mean 5.2 \pm 6.8 days) than cyclic dosing (mean $11 \pm 8.5$ days; $p=0.005$ ). Both groups had less bleeding over time; however unpredictable breakthrough bleeding was more common in the continuous regimen cohort ( $37.6 \pm 38.8$ vs $18.3 \pm 17.2$ days $)$.

These healthy, normal women taking continuous active pills had less associated menstrual pain and a favourable improvement in 'behaviour' during the premenstrual phase only. Perhaps a greater improvement would be expected if the study were to be repeated in those with premenstrual syndrome or dysmenorrhoea.

Women taking the continuous regimen had greater ovarian and endometrial suppression with one woman ovulating once. In the cyclic group rebound ovulation or suspected ovulation occurred in 11/60 cycles (18\%). These results suggest that continuous therapy should be more efficacious, however this needs to be borne out in practice.

Reviewed by Diana Mansour, FRCOG, FFSRH Consultant in Community Gynaecology, Contraception and Sexual Health Service, Newcastle upon Tyne Primary Care Trust, Newcastle upon Tyne, UK
Safety and efficacy of a single-rod etonogestrel implant (Implanon): results from 11 international clinical trials. Darney P, Patel A Rosen K, Shapiro LS, Kaunitz AM. Fertil Steril 2008; [Epub 17 April 2008]

Implanon ${ }^{\circledR}$ (etonogestrel implant) is currently the only contraceptive implant licensed in the UK and is familiar to most general practitioners and sexual and reproductive health care workers. This report, funded by Organon, provides an overview of the implant's efficacy, safety and bleeding patterns. It is a summary of the findings of 11 clinical trials undertaken in contraceptive clinics in the USA, Chile, Asia and Europe.

In the 942 patients enrolled, no pregnancies occurred with the implant in situ, but there were six reported pregnancies within 14 days of implant removal. This gave a cumulative Pearl index of 0.38

Of the adverse events reported, those that were most likely to be attributed to the implan included headache $(15.5 \%)$, weight gain $(12.0 \%)$, acne $(11.8 \%)$, breast pain $(10.2 \%)$, emotiona lability $(5.8 \%)$ and abdominal pain $(5.2 \%)$ Complications from implant insertion and removal were infrequent.

Due to the progestogen content of the implant, bleeding irregularities were expected and occurred commonly, with no particular pattern. Comparisons between the bleeding patterns of patients using Norplant ${ }^{\circledR}$ and Implanon were made, and showed Implanon to cause fewer bleeding and spotting days and more amenorrhoea. However, the statistical significance of these findings is limited by the small number of subjects involved in this part of the analysis

Interestingly, geographical differences were noted when considering reasons for discontinuation. In the North American and European populations, bleeding irregularities were considered much less acceptable, contributing to $14 \%$ of premature removals of the implant compared to only $4 \%$ in Southeast Asia, Chile and Russia. Side effects that were reported as reasons for discontinuation more frequently also showed regional differences with symptoms such as emotional lability, depression and weight gain more commonly cited by North American patients.

This report highlights the contraceptive effectiveness of Implanon and its genera tolerability; however, the geographical variation in results must be considered when counselling patients in the UK about common side effects and bleeding patterns in an attempt to minimise patient dissatisfaction. In addition, patients with a high body mass index were excluded from the studies, therefore these trials do not predict efficacy of Implanon in obese women.
Reviewed by Kate L Darlow, MBChB, DFSRH, Specialist Registrar, St John's Hospital,

Livingston, West Lothian, UK

Male hormonal contraception: a double-blind placebo-controlled study. Mommers E, Kersemaekers WM, Elliesen J, Kepers M, Apter D, Behre HM, et al. J Clin Endocrinol Metab 2008; [Epub 15 April 2008]

A hormonal contraceptive for men has been the subject of active research for over 50 years. During this time a large number of studies have been carried out that have clearly demonstrated a number of important points including, most crucially, that hormone-induced spermatogenic suppression can provide effective contraception for men, and that this is fully reversible. This can be achieved either with high doses of testosterone alone or, to reduce the dose, the testosterone is more usually given in combination with a progestogen, which is the case in this study.

Studies in this field have often been limited by small sample size and difficulties in comparing different treatments. It is therefore very encouraging to learn of this double-blind placebo-controlled design involving 354 men who received either a low- or high-release etonogestrel implant (the low-release implant being similar to Implanon ${ }^{\circledR}$ ) combined with one of three testosterone regimens using the longacting injectable formulation testosterone undecanoate or placebo.

Overall, this was a test of very effective regimens, and the placebo group was useful in highlighting the specific side effects. However, as in many previous studies there remain a small number of men who seem resistant to hormonal suppression, and therefore should this type of approach become widespread in use then a test of efficacy, as for example after a vasectomy, would need to be incorporated. Differences between groups were slight.

Disappointingly, however, both Organon and Schering have announced that they do not intend to pursue this line of research. Optimism is only maintained by the ongoing efforts of bodies such as the World Health Organization and the National Institutes of Health who continue to be active in this field.

Reviewed by Richard A Anderson, PhD, MRCOG Professor of Clinical Reproductive Science, Centre for Reproductive Biology, Queen's

Medical Research Institute, University of Edinburgh, Edinburgh, UK 